\title{
Institute earns healthy respect
}

\section{Rlo de Janelro}

THE Oswaldo Cruz Foundation's grounds are ringed with fences, walls and armed guards who harbour deep suspicions about strangers. Presentation of a copy of Nature will in no way convince them of one's good intentions. That and the baroque architecture of the 'Moorish Pavilion', set on a hill amid dark trees above, suggests one may have accidentally stumbled on a secret military organization rather than a biomedical foundation.

Later, an explanation emerges. The foundation, on the northern outskirts of Rio de Janeiro, is ringed with favelas. A tute supplies much of the world's yellowfever vaccine.

The production facilities aside, the institute feels little different from a university. But the focus is on "endemic diseases and their vectors", research director Carlos Médicis Morel explains, with the link between research and production clearly in mind. The institute's 200 researchers are expected to publish in international journals and to be capable of true international collaboration - "Not the old kind where we have the diseases and they have the technology", says Morel.

Grants from the World Health Organization provide foreign currency and allow some items to be obtained on a 'diplomatic' basis through the Pan American Health Foundation. The result is a miracle in Brazil - Morel is able to order shortlived isotopes by telex from abroad and see them delivered in 24 hours. "There is a fight for every microlitre", he says.

A new biotechnology department is to combine research and pilot plant production and will concentrate on diseases transferred by the blood - including AIDS, malaria, syphilis and, of course, Chagas' disease.

Chagas' disease, named after the former director, is still both an important research topic at the institute and a major health problem in Latin America. As many as $10-12$ million people are affected. Modern medicine has not cured the illness but has brought new modes of transmission. In Brazil, 20,000 people a year are infected through contaminated blood transfusions, perhaps more than the number infected by insect bites. Despite the scale of the problem little was done until AIDS arrived. Previously, poor people were commonly selling blood to private transfusion banks. That is now illegal (thanks in part to the institute's lobbying). But the change banknote. has come too late for haemophiliacs. virus.

Morel, when not wearing his research director's hat, runs a group developing DNA probes for diagnosis of Chagas' disease. Samuel Goldenberg, a young molecular biologist returned from Paris, is trying a different approach, using recombinant antigens.

Diagnostic kits in use now cross-react with antigens of other diseases. His group has cloned several Trypanosoma cruzi surface antigen genes, and one has good potential for use in a test kit.

Goldenberg has a fine sense of the differences between laboratories here and in Paris and the pains and joys of working in Brazil. His field is the molecular biology of development.

"Elsewhere", he says, "I would probably work with Dictostylium. Here I work with trypanosomes. My main interest was in basic biology. but now we may have an application for our work. When you feel your science is being used for something useful its very very good."

His group has found factors that trigger the switch from the nonreplicative stage of $T$. cruzi to the replicative stage and is looking for enzymes important in the differentiation process. If enzymes unique to the trypanosome can be found, therapy with specific inhibitors may be possible.

Goldenberg's laboratory is overcrowded to bursting point. The corridors are so full of equipment that if two people meet they have to work out a way of backing into the remaining spaces in order to get past one another. If three or more people meet, the moves become just too complex - it is better just to return to one's room.

Goldenberg says that he sometimes "gets really fed up with the difficulties", that "he cannot hire new staff but is simply sending people abroad", that the strict importation rules mean that he is "treated like a smuggler" and that foreign journals come by sea, "three or four months late". But, he says, "the ambition here is not to publish, publish, publish as in the United States - we do want to publish but the main goal is to train more people".

In mid-October, Goldenberg was busy Health School which trains most of Homma the institute's director, is clearly proud that the institute helped to write Brazil's new constitution.

Half the institute's budget comes from the government and a third from the sale of vaccines. Vaccine sales are important, says Homma, because that means "we have our own budget, produced by ourselves which we can invest by ourselves". Production is being built up further with national self-sufficiency the goal. Polio vaccine is still all imported but the insti-

rying to organize the 16th Annual Meeting on Chagas' disease and leishmaniasis, due to begin a few weeks later at a resort hotel. Six hundred participants were expected. The organizers pay for research students' accommodation, "otherwise the students won't be able to go", says Goldenberg, "and its a good opportunity for them to meet people, find a place to do a postdoc. But it is a hard task because we cannot find any funds!" When last seen, Goldenberg was listening to the manager of the hotel shouting, "When will you send the money. When will you send the money?" over the telephone. In Brazil there usually seems to be some way to fix the impossible - no doubt the conference went well. 